\title{
DGCR8 wt Allele
}

National Cancer Institute

\section{Source}

National Cancer Institute. DGCR8 wt Allele. NCI Thesaurus. Code C92664.

Human DGCR8 wild-type allele is located in the vicinity of 22 q11.2 and is approximately $32 \mathrm{~kb}$ in length. This allele, which encodes microprocessor complex subunit DGCR8 protein, is involved in the modulation of microRNA biosynthesis. Deletion of this chromosomal region is associated with DiGeorge syndrome and loss of the gene may be associated with schizophrenia. 